\title{
Enhancing Teacher Professionalism in Learning Organization Perspective
}

\author{
Muammal Jasin \\ Department of Educational Management \\ Universitas Negeri Surabaya \\ Surabaya, Indonesia \\ muammal.18019@mhs.unesa.ac.id
}

\begin{abstract}
This paper analyzes the improvement of teacher professionalism through personal and organizational approaches. This study uses the library approach. Increasing the professionalism of teachers with the concept of learning organizations emphasizes that individuals in organizations must have a clear concept that is through a learning organization approach consisting of Personal mastery, Mental models, Shared vision, Team learning and System thinking. With this learning organization approach, it is able to improve the professional competence of teachers in schools so that the process of teaching and learning activities in the classroom is able to educate the nation's children to become friends and educated.
\end{abstract}

Keywords-learning organization; teacher professionalism; organization perspective

\section{INTRODUCTION}

The teacher is the most important element in the education process. Without teachers, education is only a slogan and an image. Because all forms of policy in the education sector will ultimately determine the achievement of the goals of education as teachers. The teacher becomes the central point and the beginning of all education development.

Quality education is born from qualified and professional teachers, they are the spearhead in improving the quality of education. Professional teachers are well-educated and welltrained people, and have rich experience in their fields [1].

In the Law on Teachers and Lecturers, Chapter 1 Article 1 states that teachers are professional educators with the main task of educating, teaching, guiding, directing, training, evaluating, and evaluating students in early childhood education, formal education, basic education and secondary education. Then in the next paragraph it is explained that a professional is a job or activity carried out by a person and becomes a source of income for life that requires expertise, expertise, or skills that meet certain quality standards or norms and requires professional education.

According to Hamalik [2], the teacher's professional assignments include: 1 . Acting as a model for its members. 2. Stimulating thoughts and actions. 3. Leading planning in subjects. 4. Providing advice to the executive teacher according to the needs of the team. 5. Caring and maintaining professional literature in learning area. 6. Acting or providing services as human resources in certain learning areas with reference to in-service, training and curriculum developers. 7. Develop curriculum files in specific learning areas and teach in the largest classes. 8. Maintain relationships with parents and giving comments or reports. 9. Acting as a teacher in his team.

The problem of teacher professionalism is a serious matter that must be considered. Muhibbin [3] mentions the low level of competence of teacher professionalism, teacher mastery of the material and teaching methods that are still below the standard, as the cause of the low quality of teachers which leads to the low image of the teacher

Learning organization as one solution to various managerial and human resources problems in schools. By applying this paradigm, it is expected that the school as an institutional organization is willing to always learn continuously, each component of the school organization, such as teachers, administrative staff, and principals, can always detect their own shortcomings or mistakes in an effort to improve their competence. Competence as an attitude and behavior character, or individual abilities that are relatively stable when facing a situation in the workplace [4].

Schools with all their components not only teach students but the school institutions themselves must also learn. This is based on a new concept in organization that elevates the learning paradigm of the organization. School is an organization whose goal success is largely determined by the leadership style and organizational paradigm held jointly by all components of the school.

According to Senge [5], the success of an organization, including schools, is largely determined by its ability to develop its institutions into a learning organization. The essence of learning organizations is learning. Only schools that want to develop their institutions become learning organizations, willing to learn and improve themselves continuously which will progress and continue to develop. On the other hand, schools that do not develop into learning organizations will not develop, even the school will become extinct. Therefore, schools need to develop their institutions into learning organizations through organizational learning.

In order to improve the quality of the professionalism of an educator, the author would like to examine the improvement in the quality of educator professionalism through a theory, namely the concept of a learning organization. The concept of 
learning organization consists of: analyzing personal mastery, mental models, shared vision, team learning and system thinking.

\section{METHOD}

This research is library research. Library study or literature can be interpreted as a series of activities relating to the method of collecting library data, reading and recording and processing research materials [6]. Based on this, the technique of collecting data is by identifying, analyzing and / or exploring several journals, books and documents (both printed and electronic) and data sources and / or other information that is considered relevant to research or study. The author examines the remembrance of professional teachers by using the perspective of a learning organization theory. The technique used in data analysis is the Miles and Huberman models. In this model, qualitative analysis activities are carried out interactively and continuously until it feels sufficient

\section{RESULTS AND DISCUSSION}

In accordance with Republic of Indonesia Law Number 14 of 2005 concerning Teachers and Lecturers Chapter 1 Article 1 paragraph 1 that Teachers are professional educators with the main task of educating, teaching, guiding, directing, training, evaluating, and evaluating students in early childhood education pathways formal education, basic education, and secondary education.

The concept of learning organizations emphasizes that individuals in organizations must have a clear concept, how organizations can work effectively, and efficiently in achieving their goals and objectives. Organizations as a group of people who work in a coordinated manner to achieve common goals through a particular container [7].

To become a quality school, it is necessary to implement and develop the principles of learning organizations in schools as follows:

\section{A. Personal Mastery}

The Personal Mastery is the discipline of constantly clarifying and deepening our personal vision, of focusing our energies, of developing patience, and of seeing reality objectively [5].

Personal Mastery is dedicated to continually improving and perfect skills, a discipline of continuous clarifying and deepening one 's personal vision, energies, and patience [8].

Private mastery is also a learning activity to increase our personal capacity to create the most desirable results, and create an organizational environment that encourages all members to develop themselves towards the goals and objectives they choose [9].

For that, there are at least three important steps that must be done, namely:

- Personal Vision

Personal vision is a picture of the life someone wants to achieve in the future. Generally, everyone has goals and objectives, but without a clear understanding of vision. When a teacher chooses his job to be a teacher, the orientation of the teacher is not to the material, but the orientation is more to serve to advance education. When the teacher has a strong vision that is in harmony with his profession, then he will make every effort to improve his competence in the vision of realizing his vision.

- Creative Tension.

Reality is not always the same as expectations, there is a gap between one's vision and reality. This gap will lead to two possibilities, namely emotional tension or creative tension. Emotional tension is adjusting vision to reality, but creative tension is to attract the reality that exists towards the vision that has been set.

Professional teachers will choose creative tension by utilizing those gaps to produce the power of change, not reduce the vision to adjust the reality. They remain firm with the truth of their vision.

- Commitment to vision

A strong willingness to carry out the vision, strive to stand up when facing conditions that can weaken the vision. It is this spirit that must be possessed by the teacher in carrying out their duties at school.

Teachers who have good personal mastery will certainly have high enthusiasm and commitment. This high commitment is shown by always maintaining teacher ethics, prioritizing its main tasks, always striving to improve its knowledge, build integrity, and always strive to be better and be able to overcome the challenges that occur in carrying out its duties.

Teacher's commitment is an inner strength that comes from within the heart of a teacher and the strength of the outside itself about the task that can have a major influence on the attitude of the teacher in the form of responsibility and responsiveness (innovative) towards the development of science and technology. Broader commitment than concern, because in the sense of commitment includes the meaning of effort and encouragement and considerable time [10].

\section{B. Mental Mode}

The mental model is related to how a person thinks deeply about why and how he or she performs an action or activity in an organization. A mental model is a map making or model framework in each individual to see how to approach the problem at hand. In other words, a mental model can be said as a self-concept of an educator, who with this self-concept he will make decisions or address the problem appropriately and well. The mental attitude that must be possessed by a teacher to create a quality educational institution is

- Honest and trust

The teacher is the person who obeys his words and is modeled on his behavior. So that this positive character 
must exist in the teacher. Because the teacher's task is not only teaching but educating, where in the process there is a transfer of knowledge and character.

Character education is the hardest aspect of education in the world of education in general, because the results cannot be directly seen by the naked eye like physical education. Even though it is difficult for character education to be a matter that is very urgent and cannot be ignored in education [11].

Ideally the success of education is not only measured by the edge's smartness and also the character that is formed in the students themselves. As we all know that the education stage is basically to want a change in students both intellectually, emotionally and spiritually

\section{- Professionalism}

Professionalism can be interpreted as a person's ability and skill in doing work according to their respective fields and levels. Professionalism concerning the compatibility between the capabilities possessed by bureaucracy and the task needs, fulfilled the match between ability and task needs is a requirement for the formation of professional apparatus. According [12] says that professional people are people who are dependable and trusted because they are skilled, have knowledge, are responsible, diligent, disciplined, and serious in carrying out their work duties.

To realize a professional attitude in carrying out the educational process requires the expertise of a teacher both cognitively, affective and psychomotor.

Professionalism is not only limited to the commitments made. More than that, it should be realized in an effort to continually develop strategies used in carrying out a profession, especially in the field of education [13].

- Critical

Critical thinking is a directed and clear process used in mental activities such as solving problems, making decisions, persuading, analyzing assumptions and conducting scientific research.

According to Mason, as quoted by Lunenburg and Ornstein [14], "The concept of critical thinking may be one of the most significant trends in education relative to the dynamic relationship between how teachers teach and how students learn. Based on the statement, it has become the teacher's duty to develop critical thinking skills in learning to hone both the ability of teachers to teach and how students learn [15].

\section{Shared Vision}

Shared Vision is a picture of the ideal future that is formed by members of the organization based on personal vision. This Joint Vision is shared, because all members have a stake in the formulation and formation. The shared vision has a big impact in building the teacher's commitment to develop a shared vision, and together formulate a strategy to achieve the vision within the school.
Teachers with the right vision will have the right view of learning, namely (1) learning is the heart of the education process, so the quality of education lies in the quality of learning, and not at school accessories at all, (2) learning will not be good, but through a particular innovation process, so that teachers are required to carry out various updates in terms of approaches, methods, techniques, strategies, steps, learning media change the "status quo" so that learning becomes more qualified, and (3) must be carried out on the basis of service, as the view that education is a service, not as a project. Teachers with innovative and independent actions have a view of hope that will not mean anything if it is not accompanied by various renewal work programs towards quality learning [16].

\section{Team Learning}

Shared Team Learning is a process of aligning and building the capacity of the team to achieve the desired goals together through training, workshops and training. In the learning process, there is no difference, whatever the background of one's life.

Team learning will be effective if the group members have a sense of mutual need for one another to be able to act in accordance with the joint plan. The ability to act is a prerequisite for creating organizational value [17].

In school organizations, teachers are required to increase their capacity and capability so that the quality increases. With this collective effort in educator learning, it can universally develop more intelligence and abilities not only individually but also in teams.

Teachers must be facilitated so that they are consciously involved in the process of mutual learning and collaborating in solving real problems they experience in school through the professional learning community.

The ability of an educational institution to synergize teacher activities as a teaching team in schools is determined by the existence of a shared vision and systemic thinking skills in formulating current scientific learning and discourses as an obligation of academic people.

\section{E. System Thinking}

System Thinking is a skill to understand the structure of relationships between various internal and external factors that influence the existence of the organization, the skills to think integrative and complete, the skills to think comprehensively, and the skills to build adaptive organizations, are disciplines needed to develop systemic learning disciplines

According to Senge [5], systems thinking includes a large set of rather formless methods, tools, and principles, all of which are oriented to seeing the interrelationships between forces, and see them as part of a shared process.

The results of teacher thinking or research are important in developing science. The ability to think systematically includes the meaning of the ability to always think and act with a holistic approach, as well as being able to think of all 
the elements related to education, from syllabus, learning strategies, learning methods and other educator's creativity to both thoughts and attitudes.

\section{CONCLUSION}

Increasing teacher professionalism is a joint effort to produce quality graduates according to the demands of the times. Increasing this professionalism can be done with various theories of educational science with the aim of increasing teacher competence.

Standard competence of teacher Professionalism as contained in the Law of teachers and lecturers or professional standards determined by experts can be achieved using the theory of learning organizations. Five principles of learning organization theory used by writers are: personal mastery, mental model, shared vision, team learning and system thinking capable of increasing teacher professionalism.

The professional teacher in question is an educator who is qualified, competent, and educator who is desired to bring up learning achievement and is able to influence the learning process of student teaching which will later produce good student learning achievements [18].

\section{REFERENCES}

[1] R. C. Nelson, Guidance and counseling in the elementary school. Holt McDougal, 1972.

[2] O. Hamalik, "Kurikulum pembelajaran,” Jakarta Sinar Graf., 2008.

[3] S. Muhibbin, "Psikologi pendidikan dengan pendekatan baru," Bandung PT Remaja Rosdakarya, 2010.

[4] L. M. Spencer and P. S. M. Spencer, Competence at Work models for superior performance. John Wiley \& Sons, 2008.

[5] P. Senge, "The fifth discipline: The art and practice of the learning organization. New York: Currency Doubleday," SengeThe Fifth Discip. Art Pract. Learn. Organ., 1990.

[6] M. Zed, Metode peneletian kepustakaan. Yayasan Obor Indonesia, 2004.

[7] A. Argandoña, "Fostering values in organizations," J. Bus. Ethics, vol. 45, no. 1-2, pp. 15-28, 2003.

[8] R. Marquardt. M. J, dan Angus, Building the Global Learning Organization. New York: Mc Graw-Hill Companies Inc, 1994.

[9] S. J. Confessore and W. J. Kops, "Self- directed learning and the learning organization: Examining the connection between the individual and the learning environment," Hum. Resour. Dev. Q., vol. 9, no. 4, pp. 365-375, 1998.

[10] N. Park and C. Peterson, "Moral competence and character strengths among adolescents: The development and validation of the Values in Action Inventory of Strengths for Youth," J. Adolesc., vol. 29, no. 6 , pp. 891-909, 2006.

[11] D. Kristanti, F. W. Ningtyas, and N. Rohmawati, "Perbedaan Ketahanan Pangan Rumah Tangga Pada Pernikahan Usia Dini dan Pernikahan Usia Ideal di Kecamatan Songgon Kabupaten Banyuwangi, Jawa Timur Tahun 2016," Bul. Penelit. Sist. Kesehat., vol. 20, no. 3, pp. 96-104, 2018.

[12] D. H. Maister, "The path to performance: What managers must do to create a high-achievement culture.(Human Resources)," Cornell Hotel Restaur. Adm. Q., vol. 42, no. 6, pp. 90-97, 2001.

[13] S. Danim, Inovasi pendidikan dalam upaya peningkatan profesionalisme tenaga kependidikan. Pustaka Setia, 2002.

[14] F. Lunenburg and A. Ornstein, Educational administration: Concepts and practices. Nelson Education, 2011.

[15] N. F. Amalia and E. Pujiastuti, "Kemampuan Berpikir Kritis dan Rasa
Ingin Tahu Melalui Model PBL," in PRISMA, Prosiding Seminar Nasional Matematika, 2017, pp. 523-531.

[16] I. Bafadal, Peningkatan profesionalisme guru sekolah dasar dalam kerangka manajemen peningkatan mutu berbasis sekolah. Bumi Aksara, 2003.

[17] B. A. Tarigan, "Learning Organization: Konsep dan Penerapan di Universitas Universitas Tama Jagakarsa," J. Ekon. Keuang. dan Manaj., vol. 11, no. 1, pp. 13-28, 2016.

[18] O. Hamalik, "Proses Belajar Mengajar, Cetakan kelima belas." Jakarta: Bumi Aksara, 2013. 